RECORDS ADMINISTRATION

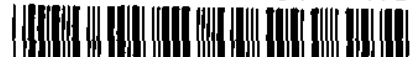

R0139054

DP-1580

\title{
COMPUTER CODES FOR DISPERSION OF DENSE GAS
}

\section{ALLEN H. WEBER AND JAMES R. WATTS}

TIS FILE RECORD COPY

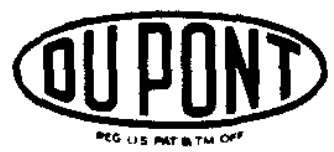

E. I. du Pont de Nemours \& Co. Savannah River Laboratory

Aiken, SC 29808

PREPARED FOR THE U. S. DEPARTMENT OF ENERGY UNDER CONTRACT DE-AC09.76SRO0001 


\section{DISCLAIMER}

This report was prepared by E. I. du Pont de Nemours and Company (Du Pont) for the United States Department of Energy under Contract DE.ACO9-76SR00001 and is an account of work performed under that Contract. Neither the United States, the United States Department of Energy nor Du Pont, nor any of their employees, makes any warranty, express or implied, or assumes any legal liability or responsibility for the accuracy, completeness, or usefulness of any information, apparatus, product, or process disclosed herein, or represents that its use will not infringe privately owned rights, Reference herein to any specific commerical product, process, or service by trade name, mark, manufacturer, or otherwise does not necessarily constitute or imply endorsement, recommendation, or favoring of same by Du Pont or by the United States Government or any agency thereof. The views and opinions of authors expressed herein do not necessarily state or reflect those of the United States Government or any agency thereof.

Printed in the United States of America

Available from

National Technical Information Service

$U$. S. Department of Commerce

5285 Port Royal Road

Springfield, Virginia 22161

Price: Printed Copy A03; Microfiche AOI 
DP-1580

UC -11

\section{COMPUTER CODES FOR DISPERSION OF DENSE GAS}

by

Allen $H$. Weber and James R. Watts

Approved by

T. V. Crawford, Research Manager

Environmental Transport Division

February 1982

E. 1. du Pont de Nemours \& Co. Savannah River Laboratory

Aiken, SC 29808

PREPARED FOR THE U. S. DEPARTMENT OF ENERGY UNDER CONTRACT DE-ACO9-76SRO0001 
Two models for describing the behavior of dense gases have been adapted for specific applications at the Savannah River Plant (SRP) and have been programmed on the IBM computer. One of the models has been used to predict the effect of a ruptured $\mathrm{H}_{2} \mathrm{~S}$ storage tank at the 400 Area. The other model has been used to simulate the effect of an unignited release of $\mathrm{H}_{2} \mathrm{~S}$ from the 400-Area flare tower. 
$\begin{array}{ll}\text { Introduction } & 7\end{array}$

Model for Puff Release Resulting from Line or Tank Rupture 8

Mathematical Model Describing the Cloud from a Liquid Spill or Jet

Stage 1: Formation of a Cylindrical Source 8

Stage 2: Slumping of the Gas Cloud 9

Stage 3: Height Growth 11

Stage 4: Transition to a Passive Puff 11

Changes and Additions to Previous Models 12

Results for Puff Dispersion from Liquid Spill or Jet 12

Wind Tunnel Model Description 16

Results for Dispersion from Unignited Flare Tower Release 18

$\begin{array}{ll}\text { References } & 19\end{array}$ 
1 Exposure (ppm-minutes) from start of the event to transition time for distances of $100 \mathrm{~m}$ and $16 \mathrm{~km}$ for different Pasquill stability categories

2 Acute effects of hydrogen sulfide gas

3 Toxicity of hydrogen sulfide to humans

4 Maximum ground level centerline concentration at $10 \mathrm{~km}$ downwind due to a puff of $\mathrm{H}_{2} \mathrm{~S}$ in different stability conditions 
1 Height growth of a dense gas cloud resulting from a 33-ton 20 release of liquid $\mathrm{H}_{2} \mathrm{~S}$ in different atmospheric stability conditions

2 Radius growth of a dense gas cloud resulting from a 33-ton 21 release of liquid $\mathrm{H}_{2} \mathrm{~S}$ in different atmospheric stability conditions

3 Concentration of $\mathrm{H}_{2} \mathrm{~S}$ versus distance downwind of the puff center for a 33-ton release of liquid $\mathrm{H}_{2} \mathrm{~S}$

4 Height growth of a dense gas cloud resulting from a 33-ton release of liquid $\mathrm{H}_{2} \mathrm{~S}$ in different atmospheric stability conditions. Same as Figure 1 except more detail of the plot is shown.

5 Radius growth of a dense gas cloud resulting from a $33-t$ ton release of liquid $\mathrm{H}_{2} \mathrm{~S}$ in different atmospheric stability conditions. Same as Figure $2^{\prime}$ except more detail of the plot is shown.

6 Concentration of $\mathrm{H}_{2} \mathrm{~S}$ versus distance downwind of the puff center for a 33-ton release of liquid $\mathrm{H}_{2} \mathrm{~S}$. Same as Figure 3 except more detail of the plot is shown.

7 The distance from the release point to initial contact point with the ground. The distance is calculated for four horizontal wind speeds for a release from the 6-inch pipe.

8 Surface $\mathrm{H}_{2} \mathrm{~S}$ concentration from an unignited flare tower release. The concentration at first contact with the ground is shown as a function of four horizontal wind speeds.

9 The distance from the release point to the initial contact point with the ground. The distance is calculated for four horizontal wind speeds for a release from a 20-inch pipe.

10 Surface $\mathrm{H}_{2} \mathrm{~S}$ concentration from an unignited flare tower release. The concentration at first contact with the ground is shown as a function of four horizontal wind speeds for a release from a $20-$ inch pipe. 
COMPUTER CODES FOR DISPERSION OF DENSE GAS

\section{INTRODUCTION}

The prediction of atmospheric concentrations of accidentally released material downwind from the point of release is of considerable interest to the nuclear and chemical industries. The Savannah River Plant handles hazardous quantities of both radioactive and nonradioactive materials. The principal hazardous nonradioactive material was $\mathrm{H}_{2} \mathrm{~S}$ which was used in quantities of several hundred tons in the process for extracting heavy water from natural water.* A previous report ( $C r a w f o r d^{l}$ ) addressed the consequences of a large $\mathrm{H}_{2} \mathrm{~S}$ release from the 400-D Area. Crawford's work treated the release as passive gas dispersion. Passive gas dispersion assumes that the gas density is nearly equal to ambient air density; thus density does not affect the dispersion. Recently, several organizations have expended considerable effort on dense gas model development and field verification. Although these efforts are incomplete because not enough field data are available, enough new results are available to substantially revise previous concepts based on passive gas behavior.

The purpose of this work was to adapt and augment existing models of dense gas diffusion and dispersion, to predict locations and concentrations during accidental releases for safety analyses, and to incorporate these models into the emergency response capabilities at SRP.

This report has categorized the releases into major types; 1) dense puffs resulting from breaks which spill or jet liquid $\mathrm{H}_{2} \mathrm{~S}$ on to the ground, and 2) dense gas plumes from unignited elevated releases. These two types of releases are modeled separately with different techniques: a mathematical model for the former, and a model from wind tunnel experiments for the latter. Although this report is concerned with $\mathrm{H}_{2} \mathrm{~S}$, the models can be applied to other dense gases with a change in a few input variables.

* The heavy water production facilities at the Savannah River Plant were shut down and placed in standby in January 1982 . 


\section{MODEL FOR PUFF RELEASES RESULTING FROM LINE OR TANR RUPTURE}

This model deals with a sudden catastropic break in a line or tank containing liquid $\mathrm{H}_{2} \mathrm{~S}$ under pressure. The model is basically the same as that proposed by Fryer and Kaiser ${ }^{2}$ who extended and improved the models by $C o x$ and Roe ${ }^{3}$ and Van Ulden. ${ }^{4}$ There are three major changes or additions which are discussed later.

Assuming a sudden catastrophic break occurs in a tank or line containing pressurized liquid $\mathrm{H}_{2} \mathrm{~S}$, several release modes are possible. For example,

- a small hole in the tank wall, resulting in a horizontal or vertical jet,

- breaks in pipes leading from the liquid space,

- jets impinging on the ground or dike wall,

- a large hole in the tank wall.

All of the above release modes result in a mixture of $\mathrm{H}_{2} \mathrm{~S}$ droplets, $\mathrm{H}_{2} \mathrm{~S}$ gas, and ambient air. Research on the percentage of $\mathrm{H}_{2} \mathrm{~S}$ droplets, $\mathrm{gas}$, and ambient air in a dense gas cloud immediately after the release is not complete. In view of this, it is desirable to deal only with a mathematical idealization of the release.

\section{Mathematical Model Describing the cloud from}

\section{a Liquid Spill or Jet}

The mathematical model describing the spill or liquid jet is divided into four stages.

- Formation of a cylindrical source

- Slumping of the gas cloud

- Height growth

- Transition to a passive puff

\section{Stage 1: Formation of a Cylindrical Source}

During this stage, the liquid and gas exit rapidly from the pressurized line or container and jets or spills onto the ground. Evaporation proceeds rapidly as the liquid portion quickly cools to its boiling temperature at atmospheric pressure. The vigorous 
boiling of the liquid causes small droplets to be thrown into the air. These droplets continue to evaporate and cool the surrounding air to the boiling temperature. Thus, a mixture of $\mathrm{H}_{2} \mathrm{~S}$ vapor, cooled ambient air, and 1 iquid droplets are the immediate result of the spill. Evaporation of the small droplets continues until a balance between droplet vapor pressure and the $\mathrm{H}_{2} \mathrm{~S}$ vapor occurs. In several accident cases that have been studied, it appeared that enough ambient air was mixed into the cloud at the outset to evaporate all of these tiny droplets. The formation of an initial cloud resulting from evaporation of droplets and cooling of ambient air was also observed in several experiments in the United Kingdom (McQuaid 5 ). A ratio of about 10 parts entrained air to 1 part dense gas was observed in tests and is assumed in the model discussed in this report.

The initial source cloud composed of $\mathrm{H}_{2} \mathrm{~S}$ vapor and cooled ambient air is idealized as having the shape of a cylinder.

The large $\mathrm{H}_{2} \mathrm{~S}$ tanks of the 400-D Area are contained within a concrete dike on the bottom, sides, and ends. The effect of the dike on the subsequent dispersion of the dense gas is not known since very few experiments have been performed. It is known that vigorous boiling will throw liquid particles high into the air space above the dike walls and thus the dike would not contain the cloud.

The dense gas cloud above the dike will elongate in the direction of the mean wind. Because the elongation is dependent on unknown details of air flow over and around the dike, a conservative assumption will be to retain the cylindrical shape of the dense gas volume throughout the puff history.

Dimensions of the initial cylindrical source are a function of the density of the mixture and the amount released. Other initial conditions needed as input to the model are the Pasquill stability class for the atmosphere, the vertical temperature difference in the lower atmosphere, wind speed, ground and air temperature, and roughness length characteristics of the nearby ground surface.

\section{Stage 2: Slumping of the Gas Cloud}

During the slumping phase, the dense gas cloud behaves similar to a liquid column flowing out of a cylindrical container under the force of gravity. This simple liquid analogy has two complications. The first is that wind shear at the top of the cloud causes air to be entrained at the top; the amount of air entrained is proportional to the longitudinal turbulence of the air $\left(\sigma_{u}\right)$ and is inversely proportional to a bulk Richardson number 
appropriate for the dense gas cloud. This Richardson number is obtained from the friction velocity, the density difference between the cloud and ambient air, and a turbulence length scale. The constant of proportionality (called the entrainment coefficient) is being established by experiments. So far, there have been only a few experiments to determine the entrainment coefficients, so this variable in the model has considerable uncertainty. A conservative estimate has been chosen for the model used here.

A second complication is that heat is transferred from the ground to the cloud as long as the ground is warmer than the dense cloud. This heat transfer is most significant if the transfer mechanism is turbulent convection. The largest contribution will be when the ground is very warm relative to the cloud. Entrained air also warms the cloud so its contribution must be included.

The equation for slumping of the cylindrical source (Yih $\left.{ }^{6}\right)$ is:

$$
\frac{d R}{d t}=k \sqrt{\left(\rho-\rho_{a}\right) \frac{g h}{\rho_{a}}}
$$

where:

$$
\begin{aligned}
R & =\text { the radius of the cylindrical puff } \\
t & =\text { time } \\
K & =\text { a constant } \\
\rho & =\text { the density of the puff. } \\
\rho_{a} & =\text { the density of the ambient air } \\
h & =\text { the height of the puff } \\
g & =\text { the acceleration of gravity }
\end{aligned}
$$

Entrainment of air through the top and edge of the cloud (Van Ulden ${ }^{4}$ ) is governed by:

$$
\begin{aligned}
\frac{d m}{d t} & =\frac{d\left(\rho_{a} V\right)}{d t}=\frac{V d \rho}{d t}+\frac{\rho d V}{d t}=\rho_{a}\left(\pi R^{2}\right) \frac{d h}{d t}+2 \rho_{a} \pi R h \frac{d R}{d t} \\
& =\rho_{a}\left(\pi R^{2}\right) v_{e}+2 \rho_{a} \pi R h \alpha * \frac{d R}{d t}
\end{aligned}
$$

where:

$$
\begin{aligned}
\mathrm{v} & =\text { volume of cloud } \pi \mathrm{hR}^{2} \\
\mathrm{~m}_{\mathrm{a}} & =\text { the mass of entrained air } \\
\mathrm{v}_{\mathrm{e}} & =\text { the entrainment velocity } \\
\alpha * & =\text { a constant for the edge entrainment }
\end{aligned}
$$


The addition of heat to the cloud is governed by an equation of the form (Fryer and Kaiser ${ }^{2}$ ):

$$
\frac{d T}{d t}=\frac{\frac{d m_{a}}{d t} c_{p a} \Delta T_{a}+\alpha\left(\pi R^{2}\right)\left(\Delta T_{g}\right)^{4 / 3}}{m_{a} c_{p a}+m_{g} c_{p g}}
$$

where:

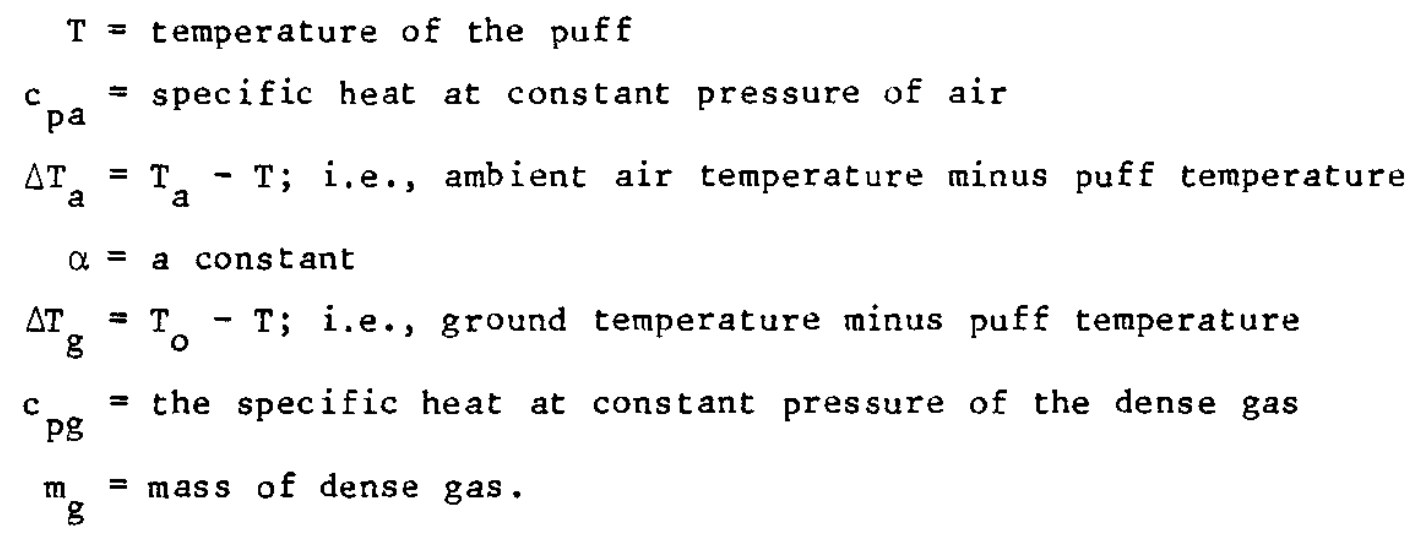

\section{Stage 3: Height Growth}

The slumping phase terminates when the cloud begins to grow in height because of entrainment of ambient air. During this stage, entrainment at the top and heat transfer from underneath continue. The cloud decreases in density and the height growth phase stops if the vertical turbulent eddies penetrate the cloud substantially. This is determined by the value of the Richardson number for the cloud as described earlier. The maximum time in this stage can be controlled in the model by limiting the Richardson number so that it does not become smaller than a certain value. Another way of terminating the model height growth stage is by limiting the cloud density to approach the ambient air density to within a small finite difference.

\section{Stage 4: Transition to a Passive Puff}

When the Richardson number criterion is exceeded, the cloud becomes a passive gas cloud whose behavior is modeled by a puff dispersion code. At present, the puff dispersion' code assumes a Gaussian model whose initial dimensions are specified from the output of the dense gas code. Thus, the source cylinder is transformed to the equivalent Gaussian shape and the dispersion proceeds from that point by specifying dispersion coefficients $\left(\sigma_{x}, \sigma_{y}, \sigma_{z}\right)$ calculated from atmospheric turbulence values. For ease of application, the passive puff code assumes Briggs rural dispersion curves (Briggs ${ }^{7}$ ). 
The model calculates the southerly component of wind velocity needed to "push" the dense cloud up a slope typical of the 400-D Area. This velocity can be calculated by equating gravitational drainage forces to the drag force of the wind. The results show that the southerly component varies from 1.6 to $1.9 \mathrm{~m} / \mathrm{sec}$, then down to 1.1 to $2.2 \mathrm{~m} / \mathrm{sec}$ as the puff evolves through Stages 2 and 3 mentioned earlier.

Tables 2 and 3 show the toxicity of $\mathrm{H}_{2} \mathrm{~S}$ to humans. All stability categories result in lethal exposures of $\mathrm{H}_{2} \mathrm{~S}$ at $100 \mathrm{~m}$ and $16 \mathrm{~km}$ downwind.

TABLE 2

Acute effects of hydrogen sulfide gas

$\begin{array}{lll}\text { Concentration (PPM) } & \text { Time } & \text { Effect } \\ 0.13 & \text { Sniff } & \text { Odor detectable } \\ 10.0 & 8 \text { hours } & \text { Threshold Limit } \\ 60-100 & 1 \text { hour } & \text { Mucous membrane irritation } \\ 200-300 & 1 \text { hour } & \text { Mucous membrane irritation (severe) } \\ 500-700 & 1 / 2 \text { hour } & \text { Coma } \\ 900 & \text { Minutes } & \text { May be fatal } \\ 1000 & \text { Minutes } & \text { Fatal }\end{array}$

Courtesy of H. W. Gerarde, M. D., Ph.D., Medical Research Division, Esso Research and Engineering Co. 


\section{TABLE 3}

Toxicity of hydrogen eulfide to humans

\begin{tabular}{|c|c|c|c|c|c|c|c|}
\hline $\begin{array}{l}\mathrm{H}_{2} \mathrm{~S} \\
\mathrm{PPM}\end{array}$ & $\begin{array}{l}0-2 \\
\text { Minutes }\end{array}$ & $\begin{array}{l}2-15 \\
\text { Minutes }\end{array}$ & $\begin{array}{l}15-30 \\
\text { Minutes }\end{array}$ & $\begin{array}{l}30-60 \\
\text { Minutes } \\
\end{array}$ & $\begin{array}{l}1-4 \\
\text { Hours } \\
\end{array}$ & $\begin{array}{l}4-8 \\
\text { Hours } \\
\end{array}$ & $\begin{array}{l}8-48 \\
\text { Hours }\end{array}$ \\
\hline $\begin{array}{l}50 \\
100\end{array}$ & & & & $\begin{array}{l}\text { Mild } \\
\text { conjunctivitis; } \\
\text { respiratory } \\
\text { troct irritation. }\end{array}$ & & & \\
\hline $\begin{array}{l}100 \\
150\end{array}$ & & $\begin{array}{l}\text { Coughing: } \\
\text { irritation of eyes; } \\
\text { loss of sense } \\
\text { of smell. }\end{array}$ & $\begin{array}{l}\text { nisturbed } \\
\text { respirat ion; } \\
\text { pain in eyes; } \\
\text { sleepiness. }\end{array}$ & $\begin{array}{l}\text { Throat } \\
\text { irritation. }\end{array}$ & $\begin{array}{l}\text { Salivat ion and } \\
\text { mucous discharge; } \\
\text { sharp pain in } \\
\text { eyes: coughing. }\end{array}$ & $\begin{array}{l}\text { Increased } \\
\text { symptoms. }\end{array}$ & $\begin{array}{l}\text { Hemorrhage } \\
\text { and death. }\end{array}$ \\
\hline $\begin{array}{l}150 \\
200\end{array}$ & & $\begin{array}{l}\text { loss of sense } \\
\text { of smell }\end{array}$ & $\begin{array}{l}\text { Throat and } \\
\text { eye irriation. }\end{array}$ & $\begin{array}{l}\text { Throat and eye } \\
\text { irriation. }\end{array}$ & $\begin{array}{l}\text { Difficult } \\
\text { breathing; } \\
\text { blurred vision; } \\
\text { light shy. }\end{array}$ & $\begin{array}{l}\text { Serious } \\
\text { irritating } \\
\text { effects. }\end{array}$ & $\begin{array}{l}\text { Hemorrhage } \\
\text { and death. }\end{array}$ \\
\hline $\begin{array}{l}250 \\
350\end{array}$ & & $\begin{array}{l}\text { Irriation of eyes; } \\
\text { loss of sense of } \\
\text { smell. }\end{array}$ & $\begin{array}{l}\text { Irritation of } \\
\text { eyes. }\end{array}$ & $\begin{array}{l}\text { Painful } \\
\text { secretion of } \\
\text { tears; weariness. }\end{array}$ & $\begin{array}{l}\text { Light shy; nasal } \\
\text { catarrh; pain in } \\
\text { eyes; difficult } \\
\text { breathing; } \\
\text { conjunctivitis. }\end{array}$ & $\begin{array}{l}\text { Hemorrhage } \\
\text { and death. }\end{array}$ & \\
\hline $\begin{array}{l}350 \\
450\end{array}$ & & $\begin{array}{l}\text { Irriation of eyes; } \\
\text { loss of sense of } \\
\text { smell. }\end{array}$ & $\begin{array}{l}\text { Difficult } \\
\text { respiration; } \\
\text { coughing; } \\
\text { irriation of } \\
\text { eyes. }\end{array}$ & $\begin{array}{l}\text { Increased } \\
\text { irriation of } \\
\text { eyes and nasal } \\
\text { tract; dull } \\
\text { pain in head; } \\
\text { weariness; } \\
\text { light shy. }\end{array}$ & $\begin{array}{l}\text { Dizziness; } \\
\text { weakness; } \\
\text { increased } \\
\text { irriation; } \\
\text { death. }\end{array}$ & Death. & \\
\hline $\begin{array}{l}500 \\
600\end{array}$ & $\begin{array}{l}\text { Coughing; } \\
\text { Collapse and un- } \\
\text { consciousness. }\end{array}$ & $\begin{array}{l}\text { Respiratory } \\
\text { disturbances; } \\
\text { irriation of } \\
\text { eyes; collapse. }\end{array}$ & $\begin{array}{l}\text { Serious eye } \\
\text { irriation; } \\
\text { light shy; } \\
\text { palpitation } \\
\text { of heart; a few } \\
\text { cases of deach. }\end{array}$ & $\begin{array}{l}\text { Severe pain in } \\
\text { eyes and head; } \\
\text { dizziness; } \\
\text { trembling of } \\
\text { extremities; } \\
\text { great weakness } \\
\text { and death. }\end{array}$ & & & \\
\hline $\begin{array}{l}600 \\
700\end{array}$ & $\begin{array}{l}\text { Collapse; un- } \\
\text { consciousness; } \\
\text { death. }\end{array}$ & $\begin{array}{l}\text { Collapse; un- } \\
\text { consciousness; } \\
\text { death. }\end{array}$ & & & & & \\
\hline
\end{tabular}

Courtesy of U.S. Bureau of Mines.

Data secured from experiments on dogs which have a susceptibility similar to humans. 
The values shown in Table 4 are the ground level centerline concentration (ppm) as the center of the cloud passes by a point $10 \mathrm{~km}$ downwind. Estimates of $\mathrm{H}_{2} \mathrm{~S}$ at $10 \mathrm{~km}$ vary from a few hundred parts per million to 17 parts per million depending on atmospheric stability.

TABLE 4

Maximum ground level centerline concentration at $10 \mathrm{~km}$ downwind due to a puff of $\mathrm{H}_{2} \mathrm{~S}$ in different stability conditions

A B $\quad \underline{C} \quad \underline{D} \quad \underline{E}$

$\begin{array}{llllll}17 & 18 & 19 & 25 & 184 & 443\end{array}$

WIND TUNNEL MODEL DESCRIPTION (Unignited Flare Tower Releases)

The release of unignited pressurized $\mathrm{H}_{2} \mathrm{~S}$ in the vapor state from an elevated stack or pipe (such as unignited gas issuing from the flare tower) is modeled by results from a scaled release in a wind tunnel. A series of tests performed at Colorado state University (Hoot, et $\mathrm{al}^{8}$ ) have application to the $\mathrm{H}_{2} \mathrm{~S}$ problem in 400-D Area. These tests were designed to find the downwind location of plume impact on the ground and the concentration of negatively buoyant fluid at the point of touchdown. The wind tunnel tests and similarity theory yield an equation to predict the horizontal distances from the stack to the downwind point of plume touchdown.

$$
x_{d}=\frac{F_{R}^{2}}{U_{o} / V} \bar{D}_{o}+0.56 D_{0}\left\{\left(\frac{H}{D_{0}}\right)^{3}\left[\left(2+\frac{h_{s}}{H}\right)^{3}-1\right]\right\}^{1 / 2} \frac{F_{R H}}{\sqrt{U_{o} / V}}
$$

where:

$$
\begin{aligned}
& x_{d}=\text { the downwind distance to the point of touchdown } \\
& D_{0}=\text { the stack diameter } \\
& H=\text { the maximum plume rise above stack height } \\
& h_{s}=\text { the stack height }
\end{aligned}
$$


$\mathrm{F}_{\mathrm{RH}}=\mathrm{a}$ horizontal densimetric Froude number

$F_{R H}=V\left(\frac{\rho_{A}}{\left(\rho_{0}-\rho_{A}\right) g D_{o}}\right)^{1 / 2}=\frac{v}{\sqrt{g^{\prime} D_{0}}}$

$F_{R}=$ vertical densimetric Froude number

$F_{R}=U_{o}\left(\frac{\rho_{A}}{\left(\rho_{0}-\rho_{A}\right) g D_{0}}\right)^{1 / 2}=\frac{U_{o}}{\sqrt{g^{\prime} D_{0}}}$

$V=$ horizontal wind velocity

$U_{0}=$ stack exit velocity

$g^{\prime}=g\left(\rho_{0}-\rho_{a}\right) / \rho_{a}$

$\rho_{0}=$ plume density at the stack exit

$\rho_{a}=$ ambient air density

$g=$ acceleration of gravity

The concentration at the point of touchdown is given as:

$x=3.10 \frac{\mathrm{Q}}{\mathrm{VD}_{\mathrm{o}}^{2}}\left(\frac{2 \mathrm{H}+\mathrm{h}_{\mathrm{s}}}{\mathrm{D}_{\mathrm{o}}}\right)^{-1.95}$

where:

$x=$ concentration, $\mathrm{kg} / \mathrm{m}^{3}$

$Q=$ source strength, $\mathrm{kg} / \mathrm{s}$

For tall stacks, where $h_{s} / H \gg 1$, the rise due to momentum flux in the stack is insignificant. These equations predict that as the amount of dense gas is increased, the distance to touchdown decreases because of the greater mass of dense fluid. On the other hand, for short stacks $\left(h_{s} / H<<1\right)$, the rise of the plume due to momentum flux dominates; thus, the distance to touchdown increases as the amount of dense gas increases because of the dominance of the momentum of the plume. 
Figures 7 and 8 show results from an unignited flare tower for release rates from $0.001 \mathrm{~kg} / \mathrm{sec}$ to $5 \mathrm{~kg} / \mathrm{sec}$ through a 6 -in. diameter line. Figure 8 shows the distance from the release point to the initial contact point with the ground. Figures 9 and 10 are similar except that the release is for a $20-i n$. diameter line. Because of the dense gas, the larger release rates will result in surface contact points at shorter distances with higher concentration. Figure 9 shows the $\mathrm{H}_{2} \mathrm{~S}$ concentration at the contact point. The results are calculated for horizontal wind speeds of 1.25 , $2.50,3.75$, and $5.00 \mathrm{~m} / \mathrm{s}$. As expected, the higher wind speeds give lesser concentrations at greater distances. The effect of ambient temperature is insignificant over the range of $0^{\circ} \mathrm{C}$ to $40^{\circ} \mathrm{C}$. 


\section{REFERENCES}

1. T. V. Crawford. Consequences of Large $\mathrm{H}_{2} \mathrm{~S}$ Releases . DOE Report DPST-72-513, E. I. du Pont de Nemours \& Co., Savannah River Laboratory, Aiken, SC (1972).

2. L. S. Fryer and G. D. Kaiser. DENZ - A Computer Program for the Calculation of the Dispersion of Dense Toxic or Explosive Gases in the Atmosphere. United Kingdom Atomic Energy Authority Safety and Reliability Directorate, SRD 152 (1979).

3. R. A. Cox and D. R. Roe. A Model of the Dispersion of Dense Vapor Clouds. Second International Symposium on Loss Preventing and Safety Promotion in the Process Industries, p 359, Heidelburg (1977).

4. A. P. Van UIden. On the Spreading of a Heavy Gas Released Near the Ground. Loss Prevention Symposium of the Netherlands, May 1974. Editor, C. H. Buschrnann, PP. 221-226, Elsevier, New York, NY (1974).

5. J. McQuaid. Proposed Large-Scale Field Trials on Dispersion of Heavier-Than-Air Gases. Technical Objectives, Health and Safety Executive, Research and Laboratory Services Division, Heavy Gas Dispersion Trials Report No. 1980/2, Red Hill, Sheffield, UK, (1980).

6. C. S. Yih. Dynamics of Non-homogeneous Fluids. The MacMillian Company, New York (1965).

7. G. A. Briggs. Diffusion Estimates for Small Emissions in Environmental Res. Lab., Air Resources Atmos. Turb. \& Diff. Lab., 1973 Annual Report, ATDL-106, USDOC-NOAA, (1973).

8. T. G. Hoot, R. N. Meroney, and J. A. Peterka. Wind Tunne1 Tests of Negatively Buoyant Plumes. USEPA Report EPA-650/3-74-003, Colorado State University, Fort Collins, Colorado (1973). 


\section{HEIGHT GROWTH}

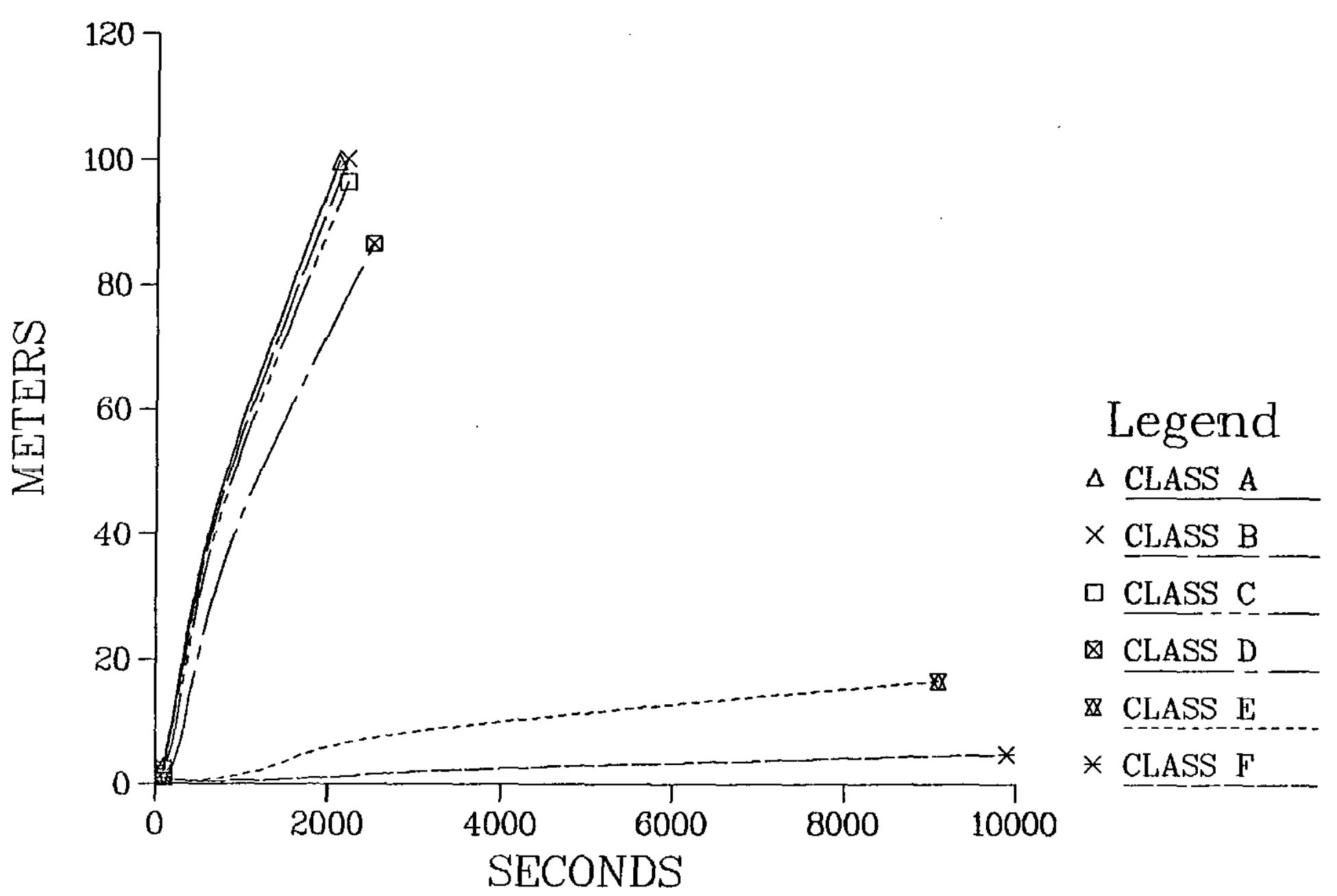

FIGURE 1. Height growth of a dense gas cloud resulting from a 33-ton release of liquid $\mathrm{H}_{2} \mathrm{~S}$ in different atmospheric stability conditions. 


\section{RADIUS GROWTH}

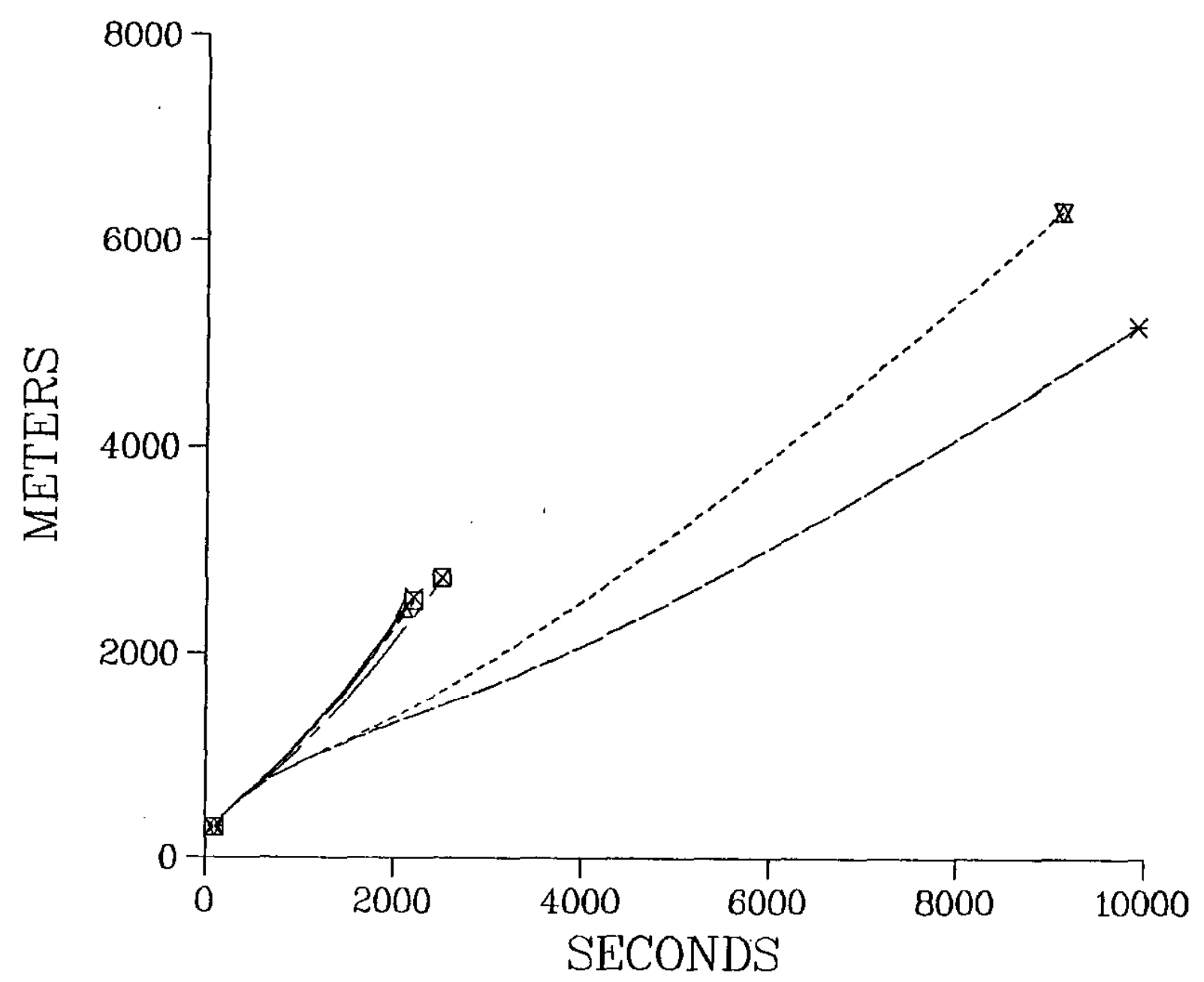

\section{Legend}

$\triangle$ CLASS A

$\times$ CLASS B

CLASS C

$\otimes$ CLASS D

$\&$ CLASS E

* CLASS F

FIGURE 2. Radius growth of a dense gas cloud resulting from a 33-ton release of liquid $\mathrm{H}_{2} \mathrm{~S}$ in different atmospheric stability conditions. 


\section{CONCENTRATION}

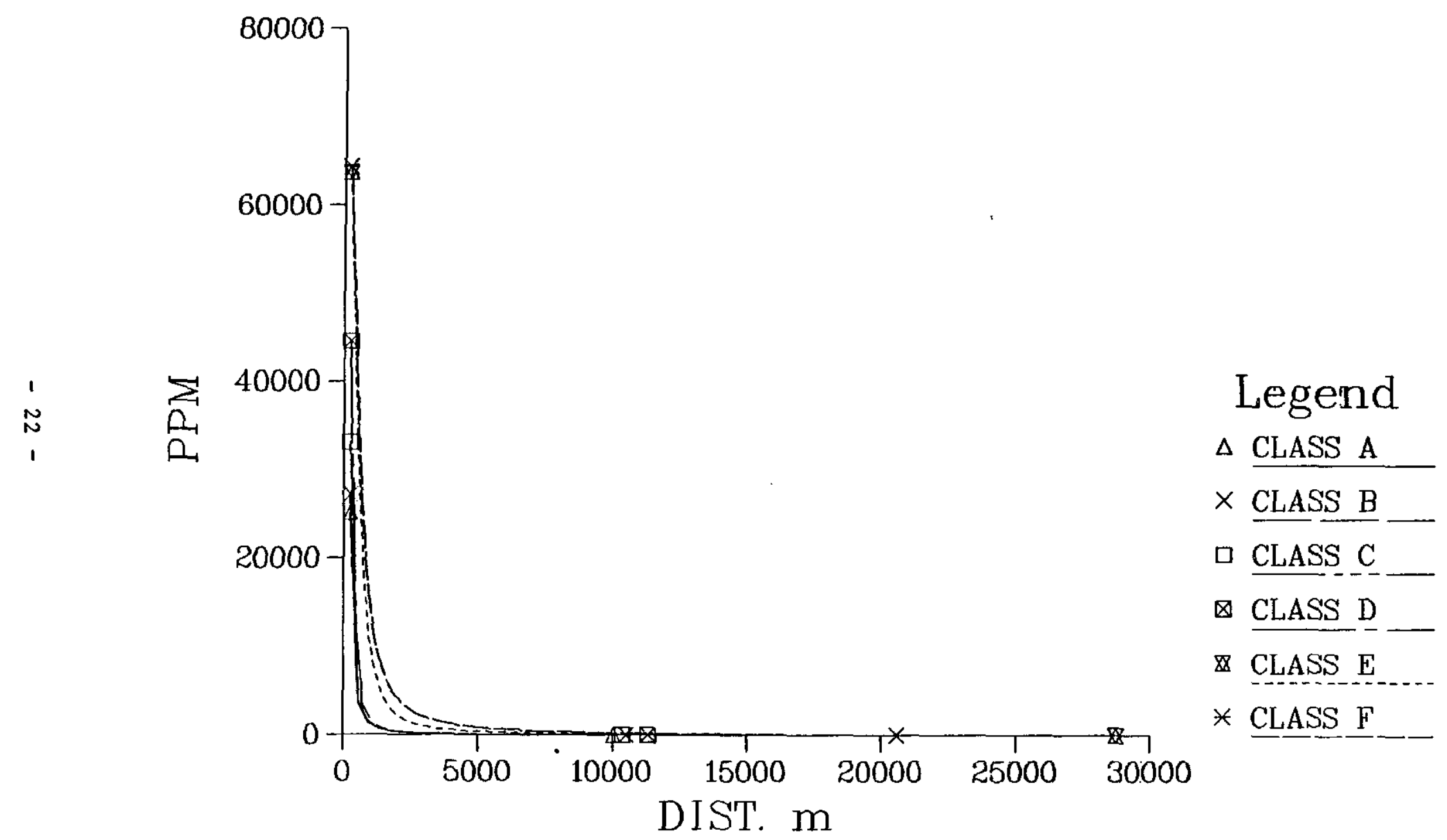

FIGURE 3. Concentration of $\mathrm{H}_{2} \mathrm{~S}$ versus distance downwind of the puff center for a 33-ton release of liquid $\mathrm{H}_{2} \mathrm{~S}$. 


\section{HEIGHT GROWTH}

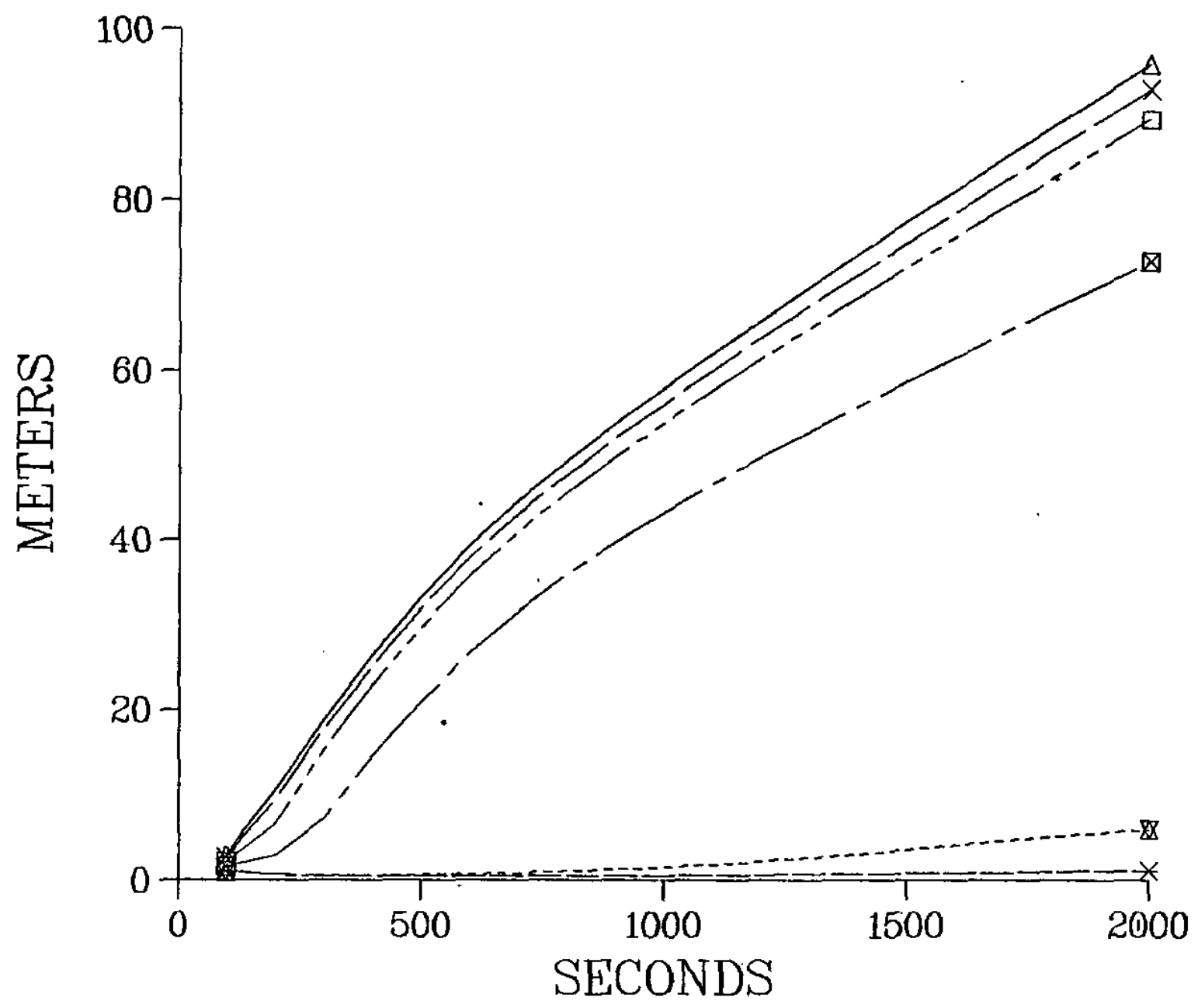

Legend

$\triangle$ CLASS A

$\times$ CLASS B

C CLASS C

$\otimes$ CLASS D

CLASS E

* CLASS F

FIGURE 4. Height growth of a dense gas cloud resulting from a 33-ton release of liquid $\mathrm{H}_{2} \mathrm{~S}$ in different atmospheric stability conditions. Same as Figure 1 except more detail of the plot is shown. 


\section{RADIUS GROWTH}

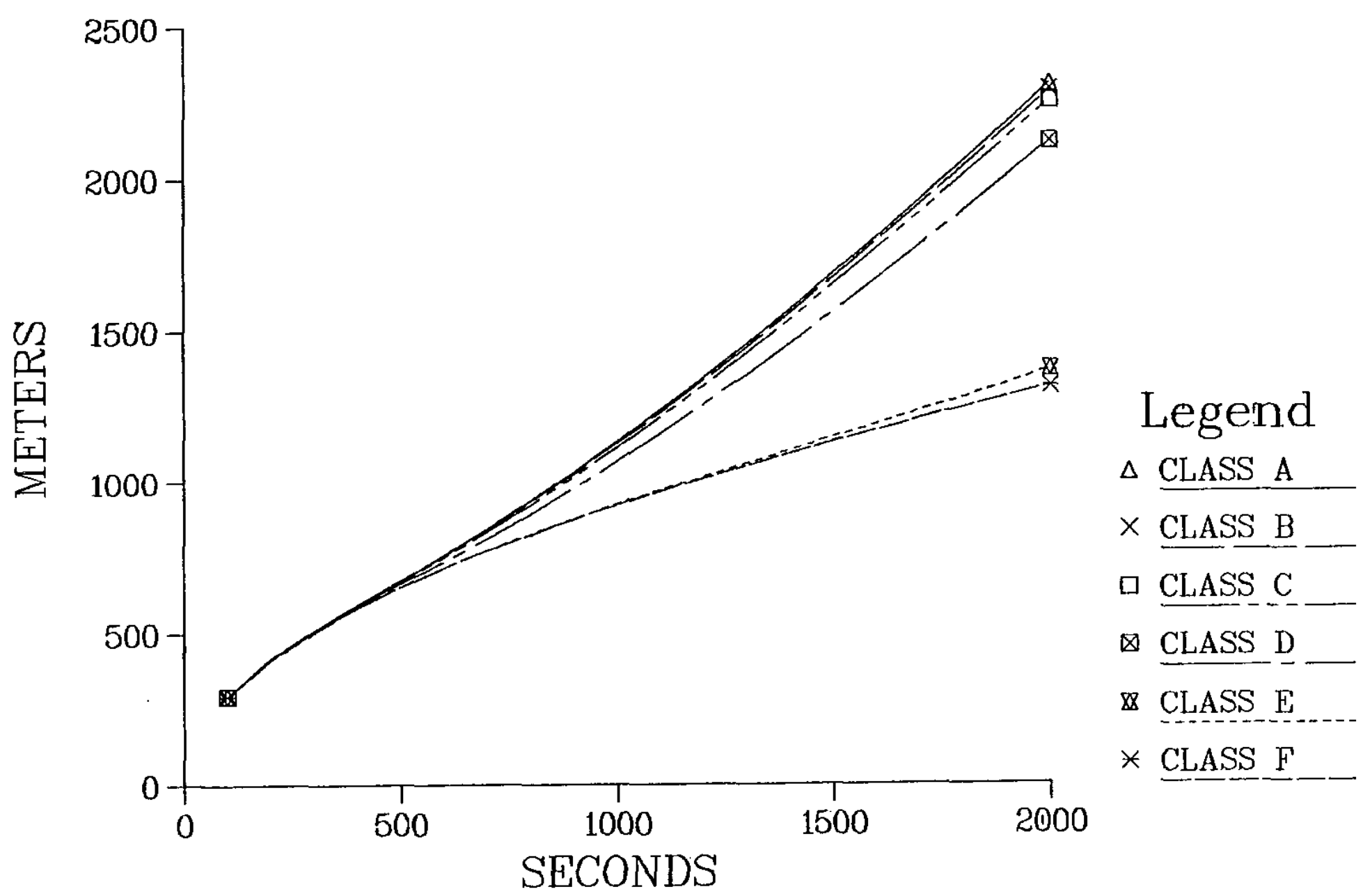

FIGURE 5. Radius growth of a dense gas cloud resulting from a 33-ton release of liquid $\mathrm{H}_{2} \mathrm{~S}$ in different atmospheric stability conditions. Same as Figure 2 except more detail of the plot is shown. 


\section{CONCENTRATION}

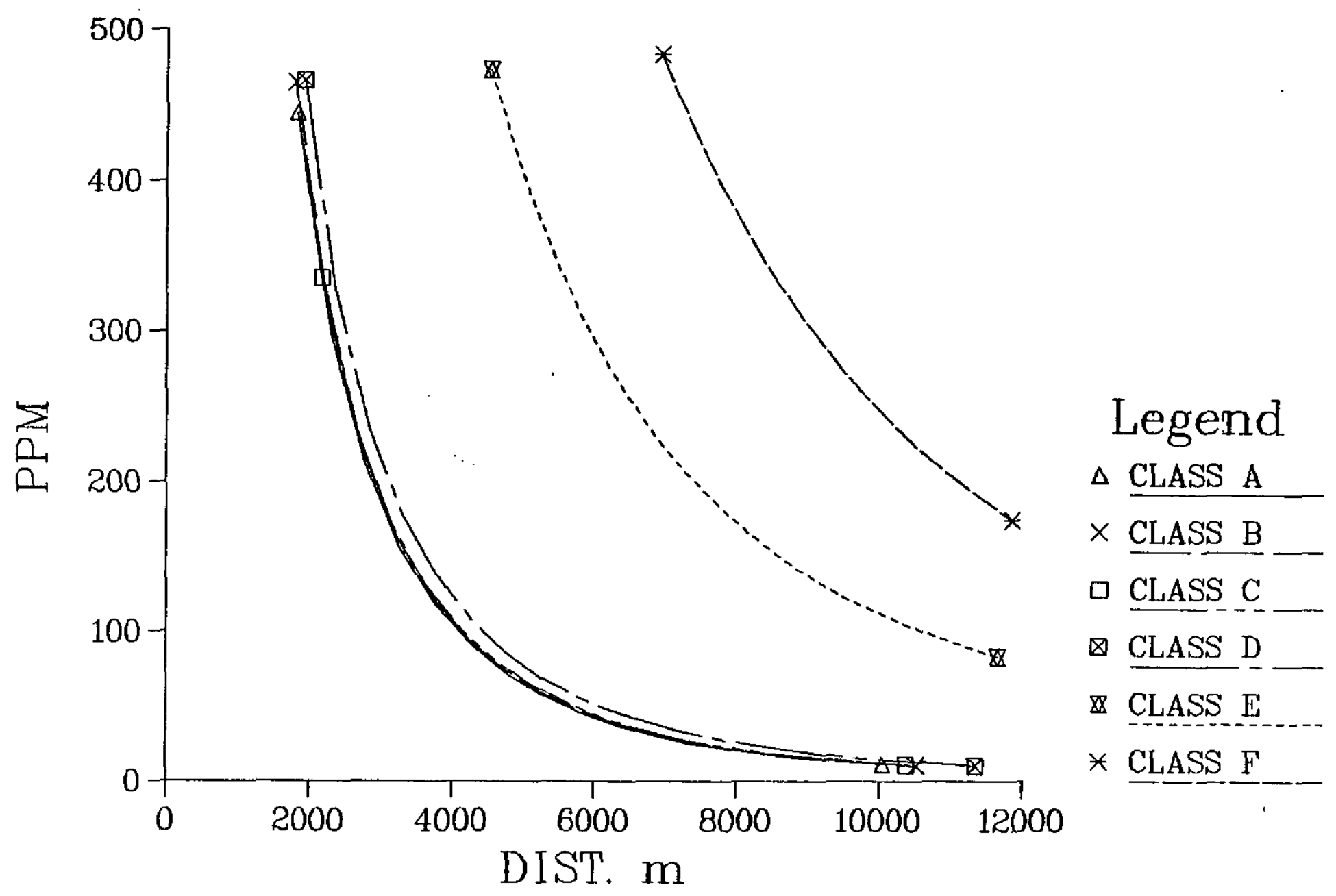

FIGURE 6. Concentration of $\mathrm{H}_{2} \mathrm{~S}$ versus distance downwind of the puff center for a 33-ton release of liquid $\mathrm{H}_{2} \mathrm{~S}$. Same as Pigure 3 except more detail of the plot is shown. 


\section{GROUND CONTACT POINT}

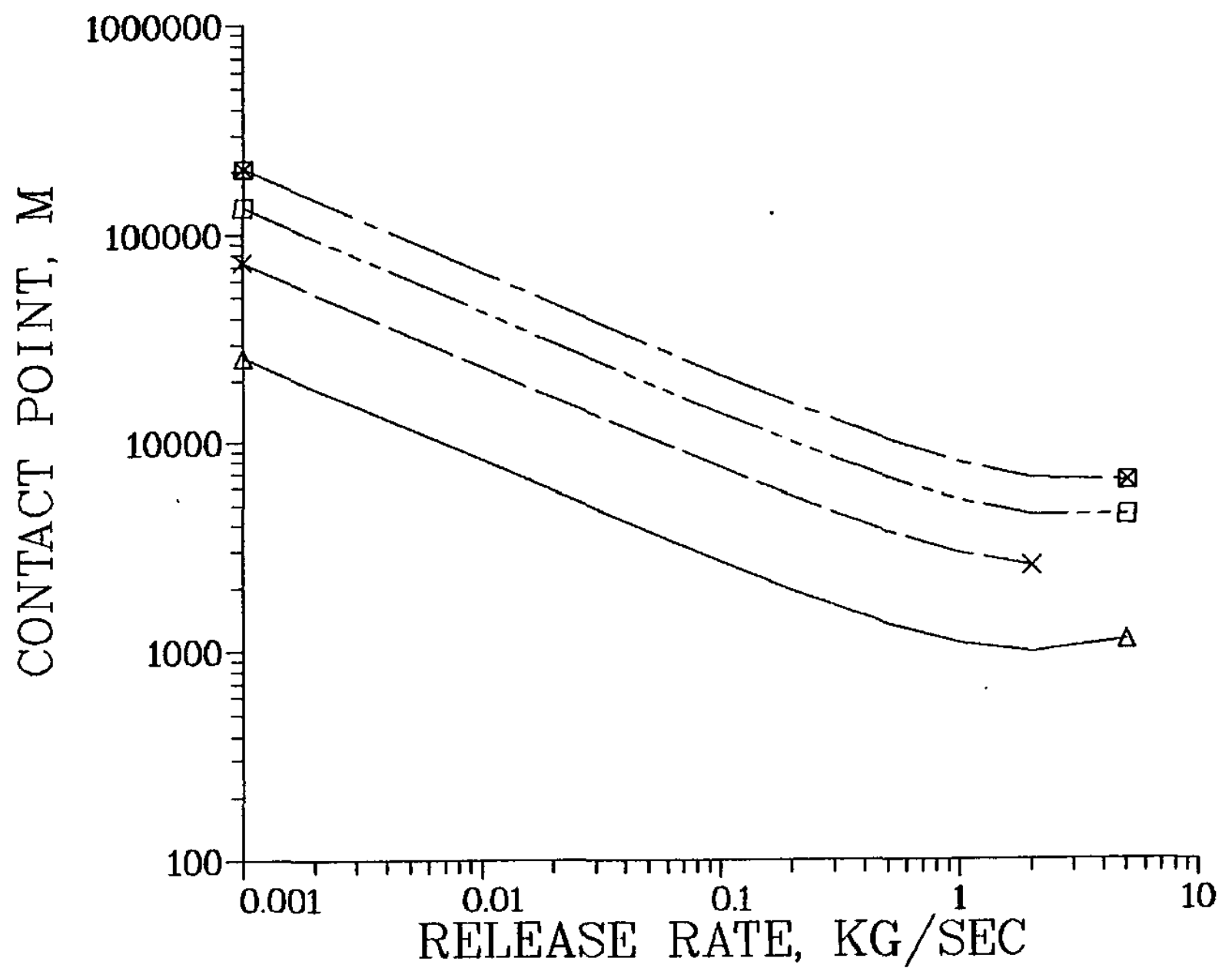

Legend

$\Delta 1.25 \mathrm{M} / \mathrm{S}$

$\times 2.50 \mathrm{M} / \mathrm{S}$

ㅁ $3.75 \mathrm{M} / \mathrm{S}$

$\otimes \underline{5.00 \mathrm{M} / \mathrm{S}}$

FIGURE 7. The distance from the release point to initial contact point with the ground. The distance is calculated for four horizontal wind speeds for a release from the 6 -inch pipe. 


\section{H2S CONCENTRATION}

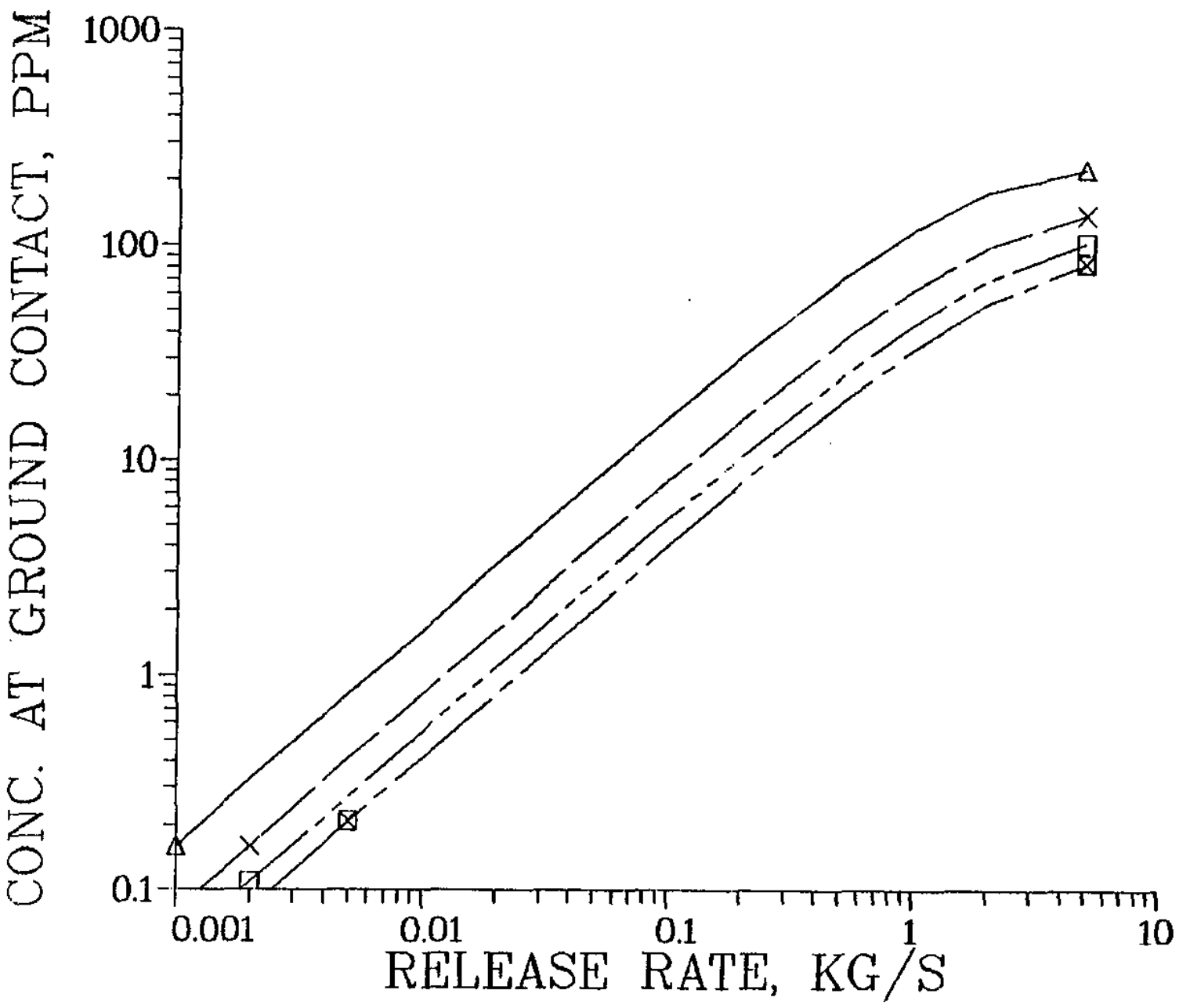

\section{Legend}

$\triangle 1.25 \mathrm{M} / \mathrm{S}$

$\times 2.50 \mathrm{M} / \mathrm{S}$

ㅁ.75 M/S

凶 $5.00 \mathrm{M} / \mathrm{S}$

FIGURE 8. Surface $\mathrm{H}_{2} \mathrm{~S}$ concentration from an unignited flare tower release. The concentration at first contact with the ground is shown as a function of four horizontal wind speeds. 


\section{GROUND CONTACT}

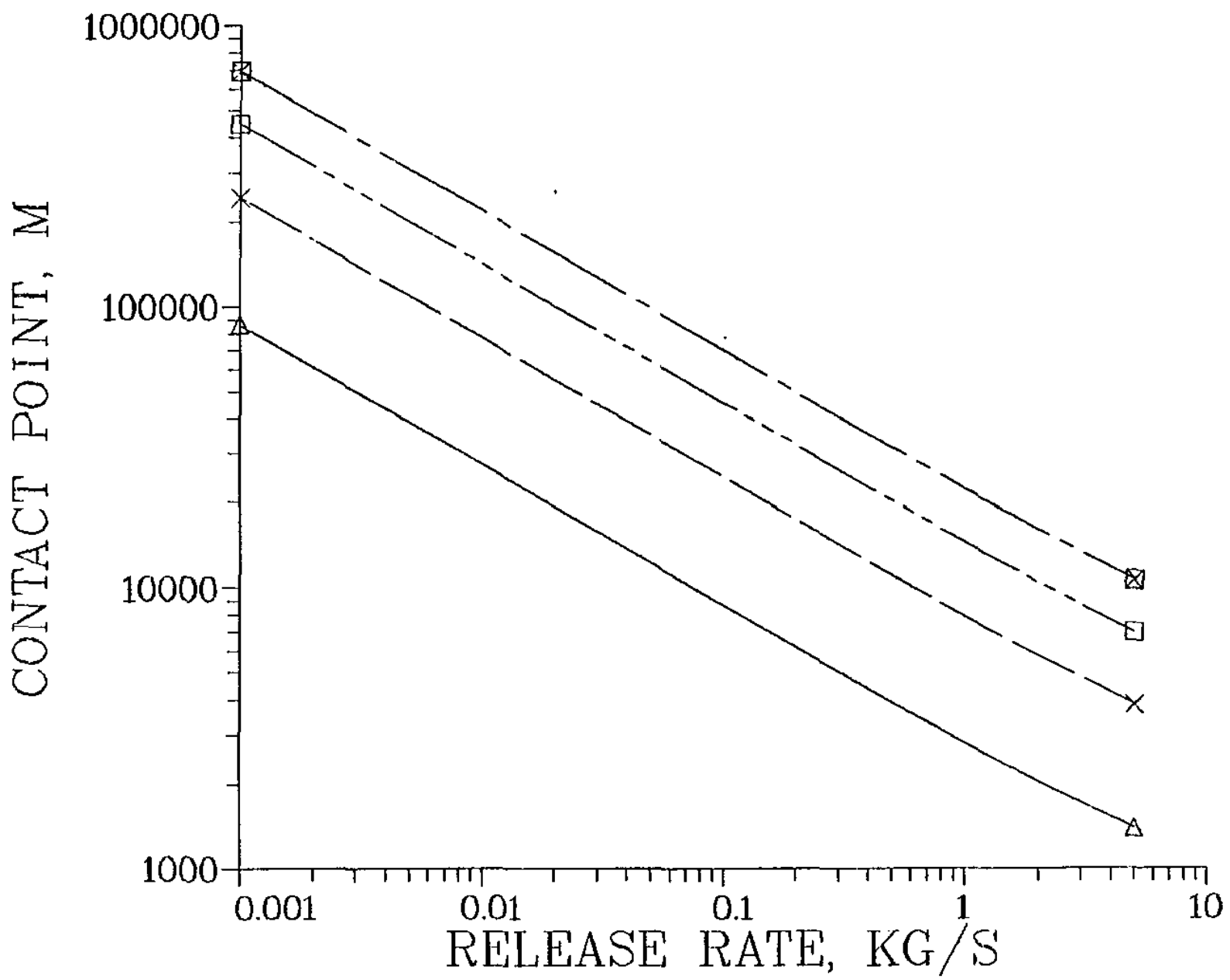

Legend

$\Delta 1.25 \mathrm{M} / \mathrm{S}$

$\times 2.50 \mathrm{M} / \mathrm{S}$

ㅁ $3.75 \mathrm{M} / \mathrm{S}$

$\otimes 5.00 \mathrm{M} / \mathrm{S}$

FIGURE 9. The distance from the release point to the initial contact point with the ground. The distance is calculated for four horizontal wind speeds for a release from the $20-i n c h$ pipe. 


\section{HLS CONCENTRATION, 20 IN PIPE}

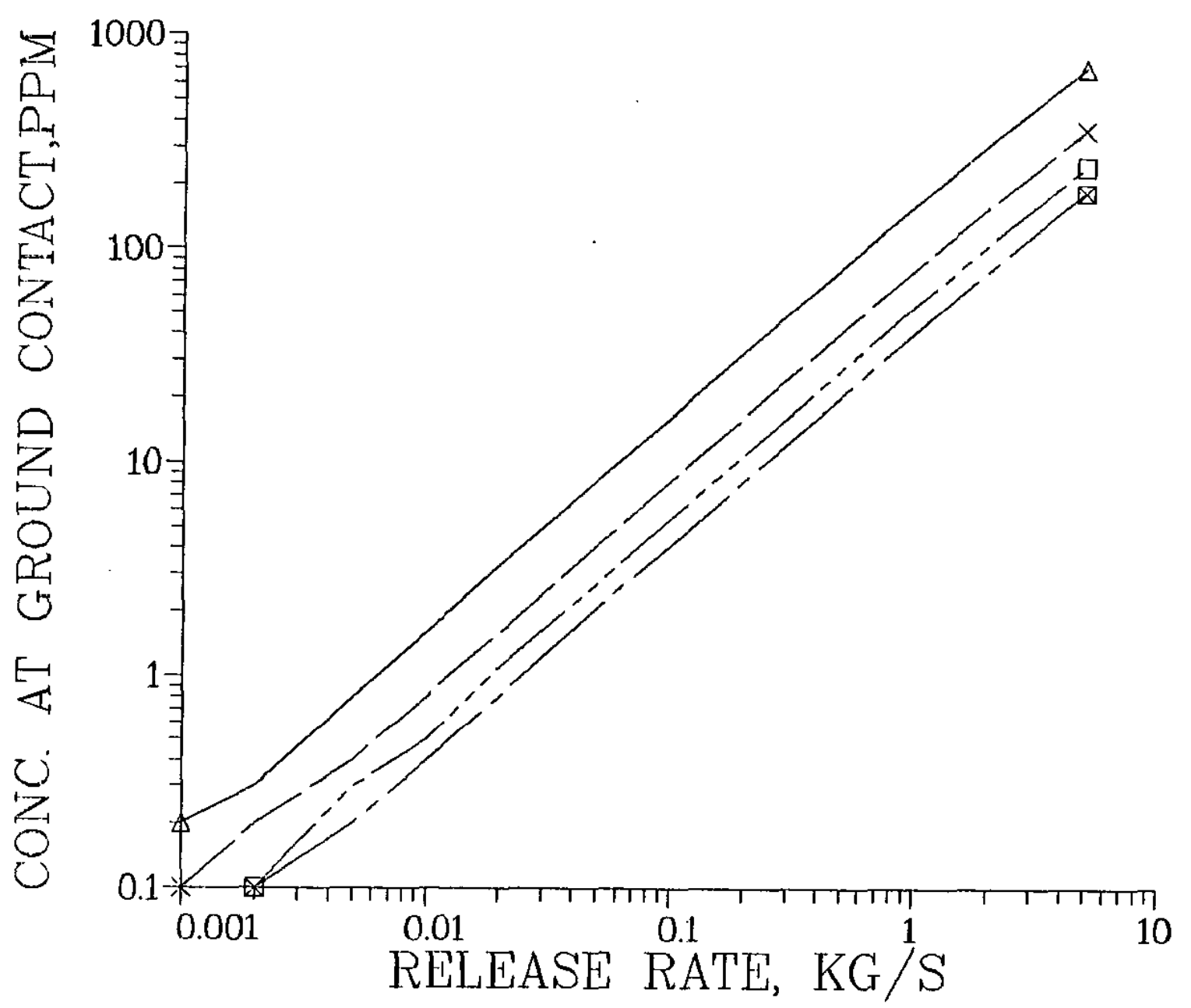

Legend

$\Delta 1.25 \mathrm{M} / \mathrm{S}$

$\times 2.50 \mathrm{M} / \mathrm{S}$

$\square 3.75 \mathrm{M} / \mathrm{S}$

$\otimes 5.00 \mathrm{M} / \mathrm{S}$

FIGURE 10. Surface $\mathrm{H}_{2} \mathrm{~S}$ concentration from an unignited flare tower release. The concentration at first contact with the ground is shown as a function of four horizontal wind speeds for a release from a 20-inch pipe. 